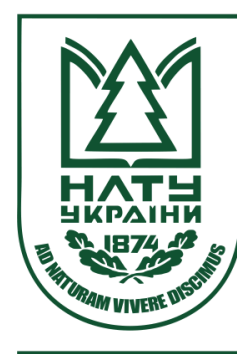

Науковий вісник НЛТУ України Scientific Bulletin of UNFU

http://nv.nltu.edu.ua

https://doi.org/10.15421/40280423

$@ \bowtie$ Correspondence author

Article received 27.12.2017 p.

Article accepted 26.04.2018 p.

B. M. Shevchyk

удк 330.[1+342]:316.42(091)

bmshevchyk@gmail.com

Б. М. Шевчик

Львівський торговельно-економічний університет, м. Львів, Украӥна

\title{
КЛІОМЕТРИКА ТА ХОЛОТРОПНИЙ ПРИНЦИП ПРАКСЕОЛОГІЇ
}

Досліджено холотропний принцип праксеології з позицій аксіологічних наративів економічної діяльності. Кліометрикоутилітаристський підхід мейнстрімної економіки визнано недостатнім для пояснення онтологічних причин економічного розвитку та зростання. Економічний розвиток бере початок як інтелектуальна біфуркація розпаковування певної множини сенсів семантичного вакууму та створення текстів - інноваційних знань про можливості нових комбінацій та доходів за результати цих комбінацій. Обгрунтовано неможливість 3 допомогою кліометричних підходів сучасної економічної науки пояснити інтегральні витоки людської взаємодії, зумовлювані атрактивністю цілей та аксіологією засобів, які відображають холотропний принцип праксеології. Мікроекономічний методологічний імператив maxutility непридатний для аналізу макро- та мегаконтинуумів економічної дійсності, оскільки холотропність, виявами якої є усвідомлена синергія волі та емерджентний ефект результатів, не виводиться із персоніфікованої жадоби в умовах світу як дефіциту. Соціокультурне середовище, - той континуум, у якому холономність світу актуалізується у патернальних практиках, - мейнстрімною наукою трактується як деструктивне обмеження вибору та зазіхання на економічну свободу. Економічні інститути, вибудувані на методологічних підходах статичної ефективності, стимулюють адаптивний потенціал когнітивного капіталу, збалансовуючи точки на кривій виробничих можливостей згідно з оптимумом Парето. Вони не стимулюють пошук ренти 3 можливостей нових комбінацій ендаументальних активів.

Ключові слова: кліометрична модель; холотропність праксеології; холономність аксіології; наратив; патерн; maxutility; симулякр; ідеаційна культура.

Вступ. Однією із тенденцій сучасної когнітивістики $€$ намагання пояснювати економічними наративами на основі математичного моделювання усі сфери людської діяльності, які стосуються як майбутнього (футуросинергетика), так і минулого (кліометрика). I така економетрична модель емансипується від обставин історичного часу, претендуючи на екуменічно-універсальний патерн пояснення світу - усього мислимого і можливого. Вона цілеспрямовано ігнорує локальні екстерналії і тому ніколи не відповідає дійсності. Однак екстраполюючись із теоретичного простору кабінетних ідилій у сферу реальної політики Бреттон-Вудських інституцій, мейнстрімівська ідеологія створює у світі більше проблем, їх вирішує. Ця ідеологія помилкова у методі: вона не там бачить онтологічне джерело атрактивності, яке трактує як універсальну модель поведінки - гедоністичний індивідуалізм раціональної ментальності, що діє в умовах світу як дефіциту, де все відомо, зважено і вирахувано. Невизначеність - це тільки міра нестачі раціональності. Чинник творчого натхнення, що здатен бачити цінності у непотребі, вона ігнорує. I саме тому інклюзивні інститути, які активують кумулятивні кола збільшуваної прибутковості через вікна можливостей та дифузію інновацій, вона пояснює явищами спонтанного порядку, які не мають свого принципу в історії. Тоді мі- мезис таких інститутів заздалегідь приречено на провал i крах усіх реформ. Але сила мейнстріму в тому, що, будучи латентно-вульгарною есенціалістською доктриною, він завжди "вмиває руки", залишаючи життя, над яким проводив експерименти, біля "розбитого корита" у формі "пасток бідності", "ресурсного прокляття", "загадки капіталу", "глухого кута", "вбивства переможця" тощо. I багато економетриків та кліометриків виспівують наукоподібні мантри його "непогрішності" у вигляді бездоганних математичних моделей досконалої та мертвої дійсності.

Натомість онтологічне джерело атрактивності, що зумовлює праксеологічну реальність, перебуває у протилежній площині - у холономному вимірі буття, де кожна індивідуальна актуалізація відображає інтегральну природу Сущого, де все ноуменально пов'язано 3 усім, де світ є дефіцитом тільки через неуцтво людей. Економічний розвиток починається як інтелектуальна біфуркація, активуючи синергію збільшуваної прибутковості через кластери інновацій, тобто виявляється інтегральний Дух Нації, сліди якого в історії зберігає етнокультурна традиція у вигляді систем символів. Кожен концепт такого символу через образ-медіатор виявляє сутнісний принцип доцільності розпаковування таких сенсів семантичного поля і створення таких тек-

\section{Інформація про авторів:}

Шевчик Богдан Михайлович, канд. екон. наук, доцент, кафедра теоретичної та прикладної економіки. Email: bmshevchyk@gmail.com

Цитування за ДСтУ: Шевчик Б. М. Кліометрика та холотропний принцип праксеології. Науковий вісник НЛтУ України. Серія Економічна. 2018, т. 28, № 4. С. 121-127

Citation APA: Shevchyk, B. M. (2018). Cliometrics and Holotropic Principle of Praxeology. Scientific Bulletin of UNFU, 28(4), 121-127. https://doi.org/10.15421/40280423 
стів, які надалі стають праксеологічними патернами, зокрема, економічними інститутами, що відображають негентропійну міру релевантності можливого й абсолютного, мислимого і первозданного, яке ще класики античної філософії визначали як Вище Благо. Аксіологічним контекстом становлення такої економічної системи може бути тільки ідеаційний тип культурної ментальності.

Аналіз останніх досліджень і публікацій. Досліджувана проблема загалом нова, оскільки є реакцією на парадигмальний проект мейнстрімної економіки. Хоча в історії економічної думки були мислителі, які трактували господарство формою інтегрального буття, зумовленого культурно, історично, етично і навіть релігійно - від Ф. Ліста до М. Вебера, С. Булгакова та Й. Шумпетера. До сучасної когорти дослідників взаємовпливу культури, історії та економіки в їх холономному синтезі належать: Ш. Бегельсдайк і Р. Маселанд, К. Фримен і Ф. Лука, Дж. Гараєдагі, Н. Фергюсон, Т. Седлачек, Х. Уерта де Сото, М. Ротбарт, І. Кірцнер, С. Марглін, К. Поланьї, К. Гірц, В. Налімов, О. Бугайов, Г. Шипов та ін.

Постановка завдання. Метою дослідження $\epsilon$ обгрунтування холономності праксеології у сфері онтологічної атрактивності функціонування когнітивних економічних систем ідеаційного типу культурної ментальності, а також з'ясування обмеженості методологічного інструментарію мейнстріму в поясненні інтегрального виміру буття культурного, історичного та економічного, зокрема, кліометрики.

Викладення основного матеріалу дослідження. Розуміння економіки як соціокультурної системи вносить істотні корективи в історію становлення і розвитку економічних систем. Цінність історичного знання прийнято трактувати кліометрично: висуваються контрфактичні гіпотези і формуються контрфактичні моделі. Контрфактичні гіпотези - це розумові експерименти, що грунтуються на умовних передбаченнях, а контрфактичні моделі - це системи рівнянь, за допомогою яких на основі статистичних даних оцінюється можливий розвиток економіки. Але цей зовні бездоганний та логічно вивірений метод має один істотний недолік, який Уерта де Сото визначає як принцип "статичної ефективності" - "добросовісна поведінка, спрямована на запобігання нераціонального використання "заданих" ресурсів" (Uerta de Soto Kh., 2011, p. 3), тобто не просто обмежених, а статично дискретних. Цей підхід ігнорує саме динамічний чинник еволюції форм економічного порядку, пов'язаний із творчим підходом "нових комбінацій" та "творчих деструкцій". Уерта де Сото пише, що "редукціоністська ідея статичної ефективності перетворилась в ідола, який вимагає принести собі в жертву буквально все" (Uerta de Soto Kh., 2011, p. 5).

Цей ментальний наратив в економічній науці з'явився під впливом механічної фізики, зокрема, другого закону термодинаміки, де поняття енергії економісти замістили поняттям корисності. Економічну ефективність почали трактувати як реалізацію вибору на основі мінімальних втрат використання обмежених економічних ресурсів. I цей мінімум втрат визначав максимум корисності (граничної продуктивності кількісно статичних і якісно одноманітних чинників виробництва). Цю ідею теоретично обгрунтовано в "оптимумі Парето", де економіку трактують як гомеостаз точок сили, у якому будь-яка модифікація погіршує корисність. Уерта де Сото констатує, що "статичний підхід до економічної теорії зводить принцип економічної ефективності до суто технічної проблеми максимізації, яку завжди можна реалізувати, ввівши через комп'ютер відповідні дані, які завжди відомі" (Uerta de Soto Kh., 2011, p. 8). Так статистично-кількісне нагромадження фактів дає розуміння міри досягнутого соціумами рівня економічного розвитку в певні історичні епохи, а ідеалізація альтернативного комбінування ресурсного потенціалу в певну історичну епоху є підставою для контфактичного прогнозування і моделювання. Так інтелект сучасності стає судилищем історії. Але що вивчає історія: систематизацію подій минулого для пояснення причинно-наслідкових зв'язків існування теперішнього таким, яким воно $€$ чи могло б бути, чи історія вивчає сам час як континуум розгортання буття, що має свою надчасову мету? Н. Фергюсон виходить 3 того, що минуле - одне, а інтерпретацій історії чимало, натомість майбутнє охоплює безліч можливих інтерпретацій і тільки одну актуалізацію. "Минуле, - пише він, - це наше єдине надійне джерело знань про плинне сьогодення і безліч майбутніх попереду, тільки одному з яких належить відбутися. Icторія - це не вивчення минулого, це вивчення самого часу... Бо не існує можливого повторення одного багатотисячного експерименту, який створює минуле... Ми не блукаємо манівцями, а йдемо стежками, і те, з чим ми зіткнулися раніше, визначає наш вибір напрямку руху - так ми зазвичай і чинимо" (Fergiuson, 2017, p. 20). Тому історія, на думку Н. Фергюсона, "пропонує прозріння" (Fergiuson, 2017, p. 21), "воскрешаючи думки предків" (Fergiuson, 2017, p. 26), а не осуджуючи недолугість їхніх дій з позицій мети сучасного аналітика. Бо якщо образ минулого репрезентує втрачені можливості, то він може виділити місце для майбутнього тільки знелюдненням цього місця.

Раціонально впорядкована модель $\epsilon$ проектом екстраполяції в часі, на основі якого майбутнє може бути передбачуване. Історія і сучасність демонструють тільки міру відхилення від такого ідеалізованого проекту. Але насправді кожен проект атрактивний, має свою мету і сучасникам вкрай важко пізнати нарації і цілі людей минулого, неспотворено "воскресити думки предків". Економіка, оскільки вона стосується людської діяльності, у своїх першоелементах суто психологічна: мотивом дії є особиста невдоволеність від існуючого стану речей. Тоді з'являється бажання володіти подразником того, що стимулює незадоволення. Бажання, оформлене в мету, постає як потреба - біологічний інстинкт, втілений у попиті, тобто залежність. У суспільстві масового споживання потреби безмежні саме тому, що бажання відтворює нове бажання. Максимізувати власну корисність, яка $є$ мірилом добробуту і яка реалізується через задоволення від споживання, можна тільки на основі раціонального комбінування існуючих засобів, завжди обмежених не стільки кількісно, скільки у доступі. Конфлікт інтересів стає невідворотним, бо можливість задоволення індивідуальної корисності перебуває у зовнішньому просторі й залежить від усвідомлення того, чого людині треба хотіти, тобто від взірця мімезису. Сучасна економіка грунтується на наративі дефіциту як симулякра, де зростаюча міра спо- 
живання віддаляється від точки насичення в міру доступності благ. Продукт набуває параметрів граничної корисності, тобто мінімізації задоволення, вже в наступну мить після його придбання, тому споживати треба постійно, заміщуючи точку свого насичення станом свого невдоволення. Тому, як наголошує Т. Седлачек, люди купують непотрібні речі за гроші, яких у них немає, у борг, що є причиною спекулятивно-фінансових криз, бо кожна "велика споживацька вечірка в борг" (Sedlachek, 2017, p. 353) має сумний кінець.

Чи так жили люди в минулому? Однозначно ні 3 трьох причин:

По-перше, час сприймали циклічно і відновлення світу полягало не у креативній деструкції технологічно неефективного виробництва, а у відтворенні через ритуал первозданного порядку в його повноті, тобто ідея гомеостазу мала онтологічне обгрунтування і була тим імпліцитним наративом, який нівелював стан незадоволення існуючим світом у людській свідомості.

По-друге, люди минулого практикували те, що Т. Седлачек називає "економікою шабату" (Sedlachek, 2017, p. 356) - наявність часового лагу, виділеного для рефлексії, для оцінки, здійсненої на основі метафізичного взірця патерна економічного порядку в його вичерпності й повноті. Така рефлексія передбачала те, чим нехтує сучасна мейнстрімна економіка - аналіз екстерналій; і тоді патерн економічного відтворення набував повноти, а отже, максимізації ефективності та корисності не на основі наративу нестачі та невдоволення, а усвідомленої референтності здійснення можливого відповідно до онтологічного проекту тієї чи іншої модальності первозданного порядку.

По-третє, імпліцитний, "невивідний надлишок недостатності" (Sedlachek, 2017, p. 355), який активує, за Дж. М. Кейнсом, "animal spirit" - імпульс до дії, реалізувався в іншому вимірі utility. Ще до часів Д. Юма, А. Сміта і Дж. С. Мілла суперечність між maxutility індивіда i maxutility соціуму мало структуру моральної градації, де перше підпорядковувалося другому згідно 3 платонівсько-аристотелівським наративом загального найвищого добра. Цей принцип порушили Н. Макіавеллі, а потім Б. Мандевіль, які трактували приватні вади як загальне благо (адже пороки людей стимулюють попит, а отже, збільшують зайнятість, спеціалізацію і поділ праці, доходи і бюджет, тобто підвищують добробут усього суспільства). Так, акцентовано на таxutility індивіда, від якого суспільне благо вже похідне, адже "невидима рука" ринку перетворює кожен егоїстичний мотив наживи в суспільне благо "добробуту нації". Оскільки індивід не може діяти всупереч своїй функції корисності, то економісти-теоретики здійснили редукцію людини до простого раціонального актора, який оптимізує свій зиск відповідно до своїх бюджетних обмежень. Внаслідок вийшла спрощена праксеологічна схема, яка виражається математично і може застосовуватися до будь-якої сфери діяльності. Економіка стала всепояснюючою наукою усіх причин людської поведінки скрізь і завжди на основі єдиного критерію осмисленої жадоби привласнення і споживання, де гірчичні зерна зла обов'язково проростають райськими плодами добра.

3 цього погляду, сучасний мейнстрім суперечить критеріям "наукової логіки" одного з апологетів сучас- ного мейнстріму К. Поппера, для якого емпірична наука - це система, що описує тільки один реальний світ конкретного (а не загального) досвіду (Popper, 2010, p. 38). К. Поппер стверджує, що кожна емпірична система має допускати можливість заперечення досвідом (Рорper, 2010, p. 41), де фальсифікація є критерієм демаркаціï, а не універсальної значущості (Popper, 2010, p. 40). К. Поппер у такий спосіб критикував "есенціалістську" парадигму К. Маркса, яка всі аспекти життя суспільства пояснювала своїм методологічним апаратом. Але ж 3 мейнстрімом теж саме: спрощеними математизованими догмами методологічного індивідуалізму намагаються пояснювати всі виміри людської природи.

Ми з'ясували, що догматизована праксеологія мейнстріму грунтується на двох аксіологічних наративах: методологічному індивідуалізмі раціональної максимізації корисності та статичній інтерпретації економічної ефективності, де не існує інформаційної асиметpiï, а ресурси неодмінно задані. Однак плинність життя передбачає постійні зміни і в економічній сфері, зокрема, динамізм суспільних інститутів та техногенні вдосконалення на основі когнітивної творчості підприємництва. Відповідальною за збереження існуючих консервативних форм відтворення соціуму вважають культуру. Окрім безлічі визначень культури, запропонуємо таке: культура - це сукупність патернальних тріад-конфігурацій, об'єднаних у патернальний ансамбль, для забезпечення суспільного відтворення через патернальні практики. У цьому визначенні ключовим $є$ поняття "патерн" - проект відтворення, який позабіологічно продукується та позагенетично передається (Arutiunov \& Ryzhakova, 2004, p. 74). Хоча культура інтегральна по суті, іiї патерни виконують детермінуючі функції, обмежуючи вибір. Отже, культура відповідальна за економічну відсталість, а суть економічного розвитку, що зводиться до більш раціонального використання наявного ресурсного потенціалу, полягає у подоланні патернальних обмежень. Тобто економічний розвиток можливий тільки в мультикультурному просторі. Однак існує закономірність: $з$ одного боку, економічний наратив utility передбачає спрощення такого вагомого вияву культури, як мова - універсального медіатора актуалізації буття (і англійська мова як засіб міжнародного спілкування це підтверджує), а 3 іншого - статичний наратив utility теж $є$ патерном (точніше сукупністю патернальних конфігурацій в мультикультурному просторі), тобто обмежувальною моделлю певного способу відтворення, яка, для потреб економічного розвитку, теж мала б бути подоланою.

Але чи справді культура - гальмо економічного розвитку? Для мейнстріму - однозначно так, бо "аргументи на захист культурної ідентичності відображають статичне уявлення про культуру, позбавлене історичного підгрунтя" (Palmer, 2014, p. 117). Для мейнстріму поняття "культурна ідентичність" "небезпечне", бо "носить нівелюючий характер" і являє собою "колективістське й ідеологізоване відсікання всього, що $є$ оригінальним і творчим в окремій особистості, усього, що не продиктоване походженням, географією і впливом середовища" (Palmer, 2014, p. 118). Натомість "глобалізація надає всім жителям планети можливість будувати свою індивідуальну культурну ідентичність за рахунок добровільних дій, відповідно до власних переваг і осо- 
бистих прагнень... У цьому сенсі глобалізація ... істотно розширює горизонти свободи особи" (Palmer, 2014, p. 118). Стає зрозуміло, що індивід може бути вільною особистістю, якщо радикально розірве зв'язки із своєю історичною спадщиною, яка визначає колективну ідентичність, і виводить власну "культурну" ідентичність на основі егоїстичного maxutility - вічного невдоволення і безмежної жадоби.

Для початку розглянемо функціональну структуру соціокультурної системи, покликаної забезпечувати суспільне відтворення через патернальні практики, тобто через економічну діяльність. Синергетична функція культури, - забезпечення розширеного самовідтворення суспільства, - реалізується взаємодією квадри блоків: блоку виробничої культури, блоку культури життєзабезпечення, блоку гуманітарної культури та блоку соціонормативної культури. Усі ці блоки утворюють аксіологічний каркас праксеології. Культура виробництва передбачає способи трансформації ресурсів у продукти. Культура життєзабезпечення формує сферу споживання. Соціонормативна культура включає право, етику та естетику, та визначає межі поведінки. Гуманітарна культура мотивує і стимулює людську діяльність (Arutiunov \& Ryzhakova, 2004, p. 79). Отож, усі блоки культури виступають наративними елементами економічної системи, тобто культура й економіка насправді невіддільні. У сучасній економічній науці дискурс про співмірність цих сфер звівся до того, чи $є$ економіка культурою, чи культура - економікою (Веgelsdaik \& Maseland, 2016).

Однак чи дійсно ціною економічного розвитку має бути вульгаризація культури? I чи дійсно культурна антропологія в історичному контексті відображає цю тенденцію? Зрозуміло, що кліометричний проект maxutility передбачає "історію без людини" (Saveleva \& Poletaev, 1997, p. 125). На увагу заслуговує той факт, що культурна антропологія вивчає не тільки культурні та етнічні відмінності, взаємодію та взаємовпливи різних соціумів планети, а зосереджується на вивченні взірців онтологічних сенсів, які проявляються у символах та визначають поведінку, а отже, і господарську діяльність: "Дивні та ірраціональні характеристики культури насправді відображають цілісність мислення, що цементує соціум" (Saveleva \& Poletaev, 1997, р. 125). Тому культура сутнісно (а не тільки формально) інтегральна, бо є "символічним світом", в якому символи зумовлюють думку і дію (Saveleva \& Poletaev, 1997, р. 126), тому "об'єкти культури треба прочитувати, а не підраховувати" (Saveleva \& Poletaev, 1997, р. 127). У структурі символу і концепт, і медіатор - це надчасові уявлення (щоправда медіатор - це образний знак, опредметнений досвідом пізнаного довкілля), покликані праксеологічно утверджувати буття у конкретних обставинах часу, i тому символ не тільки історичний, а й універсальний (ноуменальний завдяки концепту) патерн, оскільки придатний до зчитування сенсів та формування актуальних нарацій у будь-яку історичну епоху за будь-якого рівня техногенних досягнень. Символ у часі позиціонує універсальне і тому формує онтологічну спрямованість колективної свідомості. Тому уявлення про час, за визначенням П. Сорокіна (Sorokin, 2006), культурно зумовлені. Кліометрика ж суб'єктом концептуальності, що конституює нарації через патерни-медіатори, висуває інди- віда - maxutility - люциферичного людино бога, за М. Бердяєвим, життєва мета (зокрема, праксеологічні цілі) якого історично не зумовлені та культурно не детерміновані. I в цьому сенсі біржовий маклер із Волл-Стріт не відрізняється від Енкіду чи Гільгамеша.

Але тією мірою, якою економіка аксіологічна, культура - атрактивна. Оскільки економічна система є соціокультурним явищем, то вона теж атрактивна. Атрактор виявляє вищу мету системи, тобто мету надсистеми, для якої локальна система - засіб.

Вихід із ситуації Уерта де Сото вбачає у заміні концепції статичної ефективності концепцією динамічної ефективності, ядром якої була б еволюційна економічна теорія. Але проблемою залишається наратив гедоністичного maxutility. Передусім динаміка передбачає доцільність - точку відліку і напрямок руху. У миттєвості актуалізації розгортається та згортається буття - завжди інше, ніколи не повторюване. Незмінним залишається тільки сам принцип актуалізації. Когнітивна динаміка підприємницького креативу постійно зсуває криву виробничих можливостей вправо, залишаючи поза увагою самого "диригента системи" - "суб'єкта вчинку екзистенційних операцій" за Є. Слуцьким (Slutskyi \& Bazylevych, 2007). "Наявні прості сподівання", покликані матеріалізуватися у прибуток, випливають із розширення "нових можливостей розпорядження", які дають особливе знання - досвід "оптимальної смуги", що підвищує ймовірність здійснення чинністю диригента вибраного стану системи відповідно до оптимального (Slutskyi \& Bazylevych, 2007, p. 689). I так формується "видима просторінь" "дефінітивної багатообразності" емпіричної дійсності формальної праксеології Slutskyi \& Bazylevych, 2007, p. 693), яку "не можна геть чисто розкласти на кількісні взаємини точних елементів якоїсь квази-механічної системи" (Slutskyi \& Bazylevych, 2007, p. 679). Тому "формальна економіка - це не самостійна наука, а окрема дисципліна в межах формальної праксеології" (Slutskyi \& Bazylevych, 2007, p. 693).

Але якщо йдеться про макроекономічний рівень, тоді оптимальна смуга чинності диригента зумовлюється "попередньою історією системи" (Slutskyi \& Bazylevych, 2007, p. 692), а не гедоністичними наративами атомізованого індивіда в ринковому просторі, який витіснив простір соціокультурний. Когнітивні межі людського світу визначаються мовленням, у якому людина, за М. Гайдеггером, є сущою. А мовою економістів стала математика, якою і обмежився світ економіки та всі екуменічні нарації мейнстріму. Світ теоретичної економіки, на думку Т. Седлачека, має дві можливі "точки фіксації" в реальності: механізм гіпотез та емпіричне тестування результатів моделі (Sedlachek, 2017 , p. 423). Однак кліометрико-економетричні моделі не те що не мають реалістичних передумов, але виступають суперечливими вже хоча б тому, що декількома різними моделями можна пояснити одну феноменологічну дійсність. Тому економіка - це єдина наука про суспільство, істини якої є припущеннями. Це нагадує "собор із риштування" (Sedlachek, 2017, p. 437), тобто немає стін, собору, але $\epsilon$ інструментарій логічного риштування для "містерії інспірації" (Sedlachek, 2017, p. 439) на основі єдиного емпіричного шаріату безальтернативно спроектованої дійсності. 
Методологічний індивідуалізм раціонально діяльного актора по-різному проявляється в економічному просторі статичної та динамічної ефективності. У першому випадку розпорядчі можливості диригента зводяться до врівноваження точок на кривій виробничих можливостей, де кожна точка відповідає локальному оптимуму Парето, і тоді інститути зорієнтовані на відтворення таких етико-патернальних практик, щоб максимально раціонально і справедливо розподіляти існуючі обмежені ресурси через механізми дифузії інновацій. У цьому випадку, згідно з думкою Д. Норта (Nort, 2000), соціальні інститути виконують функцію "адаптивної ефективності" для досягнення суспільством економічної рівноваги, цілковитого гомеостазу усіх засобів і цілей. Принцип динамічної ефективності виходить 3 іншого наративу: кожна людина наділена уявою, у якій творить власні іманентні світи, поєднуючи непоєднуване і продукуючи образи до того часу неіснуючого. А в межах суспільства існує певний відсоток пасіонарних особистостей, наділених вродженою творчою здатністю виявляти довкола себе можливості перетворення того, що інші вважають непотребом в економічні активи й отримувати від цього зиск: прибуток і ренту. Ці люди постійно створюють нові засоби і цілі, відкриваючи цінність речей, які, завдяки їхній креативності, перетворились в економічні ресурси, тобто не були заздалегідь даними і вважались економічно безвартісними. Ці шумпетерівські аматори нових комбінацій, перманентно продукуючи інновації, постійно зсувають усі локальні оптимуми на кривій виробничих можливостей вправо, активуючи синерго-кумулятивні кола збільшуваної прибутковості, та водночас загрожуючи через творчі деструкції можливостям екстракції привласнення ренти тими, хто осягнув статус монопольної влади. Тому підприємець потребує не тільки інституціонального сприяння у доступі до венчурного капіталу, а й такої системи стимулів з боку держави, щоб максимально заохочувати ініціативу підприємницької творчості. I в цьому випадку, окрім функції адаптивної ефективності, зокрема, через системи освіти та охорони здоров'я, соціальні інститути мають виконувати функцію стимуляційної ефективності актуалізації творчої енергії креативних особистостей у формі так званих "інклюзивних інститутів" (Adzhemoglu \& Robinson, 2016) - регуляторних поведінкових патернів, організаційним ядром яких є наратив свободи.

Чи здатні сучасні кліометричні підходи бути в основі інклюзивних інститутів для того, щоб не тільки адаптовувати систему до викликів, а на основі когнітивної творчості асимільовувати виклики через перманентне винахідництво? Сумнівно, адже нагромаджений масив статистичного матеріалу економіки минулого навряд чи виявить принцип досвіду свободи, заключений в етнокультурний символ. Порівняння статистичних даних у різні періоди не перетворить історію у практичний ресурс економічного розвитку, бо, не виявивши концептпринцип у структурі символу, не може акумулювати синергію соціального капіталу на основі наративу довіри, без якого соціально-економічні інститути не можуть вважатися інклюзивними (і взагалі дієвими).

У чому полягає онтологічна суть підприємницької творчості? Людська свідомість - це інструмент розпа- ковування сенсів семантичного вакууму і створення текстів (ущільненої ймовірності актуалізації буття) за допомогою дискретів - слів і символів, тобто мовлення. Людина, будучи одним із можливих станів семантичного поля (системи з безкінечним числом ступенів свободи) та зчитуючи сенси семантичного вакууму, не тільки трансформує небуття (стан неспостережуваності) у потенційну основу реальності, будучи при цьому спостерігачем, а й, здійснюючи реінтерпретацію текстів (систематизованих словом сенсів можливих реальностей), по-новому проявляє первозданно задане, одвічно існуюче у недиференційованій єдності, перетворюючи словом потенцію (закон природи) у проявленість (матерію). Тексти постають як системи цінностей, а в інтегральному вимірі - як культура.

Якщо кожна людина наділена свідомістю - інструментом творчого розпаковування сенсів і актуалізації буття словом, то власне стимуляційна, а не тільки адаптивна, функція соціальних інститутів (а ці функції реалізуються передусім освітніми закладами) полягає в тому, щоб освітні програми містили нарації не тільки аксіологічних патернів чуттєвої культури, а й ідеаційної. У процесі навчання свідомість має бути ознайомлена 3 атрактивним виміром образного буття, 3 онтологічними першоосновами культури і нагромадженим у культурах (передусім у власній, національній) досвідом подолання суперечності між буттям і небуттям. Поруч із спеціалізованим технічним знанням акцент має бути зроблено на поширення знання гуманітарного, яке конституює внутрішній світ людини, формує холотропну свідомість на основі вищих цінностей та можливості соціально-економічного порядку, вибудуваного на патернах цих цінностей. Одним словом свідомість потрібно налаштувати на інтелігібельний спосіб світовідчуття та холономний спосіб світорозуміння - і в цьому має полягати споживна вартість освітньої послуги нооекономіки ідеаційної культури.

Отже, нехтуючи аксіологічними нараціями, кліометрика не може пояснити світ економіки в його онтологічній доцільності, оскільки абсолютизація будь-яких дискретностей невідворотно породжує суперечності і в теорії, і в житті. Натомість світ має мету там, звідки приходить Слово - у холономності Буття Сущого, для якого людина - медіатор його волі, що актуалізує універсальне в унікальному, звершуючи повноту буття у творчості. Однією із якісних модальностей такої медіації виступає підприємець-новатор.

Висновки і перспективи подалыших досліджень. Кліометричний підхід нехтує чинником динамічності економічних процесів та нівелює "дух епохи", уніфікуючи всі цілі в режимі maxutility. Аксіологічний релятивізм кліометрики сучасного мейнстріму вибудувано на припущеннях, які являють собою економетричні моделі індивідуальної раціональної поведінки в умовах інформаційної заданості ресурсів та відчутті особистої невдоволеності від дійсності. Утилітаристський наратив оцінювання трактується як універсальний, емансипований від історичного контексту, а саме цей контекст зумовлює спосіб розпаковування цінності у бутті в той чи інший період тієї чи іншої культури. Для свідомості таxutility існує єдина універсальна надісторична цінність - корисність, яку розуміють як властивість блага задо- 
вольняти потребу, тобто як засіб для досягнення задоволення. Така ментальність не сприймає ідею самоцінності буття; для неї довкілля - це простір мінових вартостей, доступ до яких пригальмовує на певний час невдоволення собою і жадобу безмежного матеріального збагачення, стимульовану цим невдоволенням. Культурні патерни у формі соціальних інститутів обмежують прояви жадоби, тому мейнстрім свідчить про деструктивну роль культури в економічному зростанні, а економічний розвиток трактує як вольове подолання гедоністом морально-етичних обмежень культурного патерна - і тільки так, на їхню думку, виникає інновація.

Кліометричний патерн maxutility, ядром якого є наратив жадоби, відкидає думку про те, що сенс історії можна привідкрити тільки на основі ідеального буття власне буття цінностей, втілення повноти буття цінностей у буття людське у такій праксеологічній актуалізації, де в історичному часі через інтелігібельний акт створення текстів, - аксіологічних сенсів семантичного вакууму, - виявляється онтологічна новизна інтегрального буття. Але саме онтологічна новизна зумовлюватиме споживну вартість інформаційної інновації в умовах ринково-мережевих відносин когнітивної нооекономіки ідеаційної культури.

\section{Перелік використаних джерел}

Adzhemoglu, D., \& Robinson, Dzh. (2016). Chomu natsii zanepadaiut. Kyiv: Nash Format. 440 p. [In Ukrainian].
Arutiunov, S. A., \& Ryzhakova, S. I. (2004). Kulturnaia antropologiia. Moscow: Ves Mir. 216 p. [In Russian].

Begelsdaik, Sh., \& Maseland, R. (2016). Kultura v ekonomicheskoi nauke: istoriia, metodolicheskie rassuzhdeniia $v$ oblasti prakticheskogo primeneniia v sovremennosti. Moscow: SPb Izd-vo Instituta Gaidara; Izd-vo "Mezhdunarodnye otnosheniia"; Fakultet svobodnykh iskusstv i nauk SPbGU. 464 p. [In Russian].

Fergiuson, N. (2017). Tsyvilizatsiia. Yak Zakhid stav uspishnym. Kyiv: Nash format. 488 p. [In Ukrainian].

Nort, D. (2000). Instytutsii, instytutsiina zmina i funktsionuvannia ekonomiky. Kyiv: Osnovy. 198 p. [In Ukrainian].

Palmer, T. Dzh. (Ed.). (2014). Moralnist kapitalizmu. Te, pro shcho vy ne pochuiete vid ekonomistiv. Kyiv: Osnovy. 128 p. [In Ukrainian].

Popper, K. (2010). Logika nauchnogo issledovaniia. Moscow: AST; Astrel. 565 p. [In Russian].

Saveleva, I. M., \& Poletaev, A. V. (1997). Istoriia i vremia. V poiskakh utrachenogo. Moscow: Iazyki russkoi kultury. 800 p. [In Russian].

Sedlachek, T. (2017). Ekonomika dobra i zla. Slidamy liudskykh poshukiv: vid Hilhamesha do finansovoi koryzy. Lviv: Vyd-vo Staroho Leva. 520 p. [In Ukrainian].

Slutskyi, Ye., \& Bazylevych, V. D. (Ed.). (2007). Vyznannia. Tvorcha spadshchyna z pohliadu suchasnosti. Kyiv: Znannia. 919 p. [In Ukrainian].

Sorokin, P. A. (2006). Sotcialnaia i kulturnaia dinamika. Moscow: Astrel. 1176 p. [In Russian].

Uerta de Soto Kh. (2011). Sotcialno-ekonomicheskaia teoriia dinamicheskoi effektivnosti. Cheliabinsk: Sotcium. 409 p. [In Russian].

\section{КЛИОМЕТРИКА И ХОЛОТРОПНЫЙ ПРИНЦИП ПРАКСЕОЛОГИИ}

Исследован холотропный принцип праксеологии с позиций аксиологических нарративов экономической деятельности. Клиометрико-утилитаристский подход мейнстримной экономики признается недостаточным для объяснения онтологических причин экономического развития и роста. Экономическое развитие берет начало как интеллектуальная бифуркация расфасовки определенного множества смыслов семантического вакуума и создание текстов - инновационных знаний о возможностях новых комбинаций и доходов за результаты этих комбинаций. Обоснована невозможность с помощью клиометрических подходов современной экономической науки объяснить интегральные истоки человеческого взаимодействия, предопределяемые атрактивность целей и аксиологию средств, отражающие холотропный принцип праксеологии. Микроэкономический методологический императив maxutility непригоден для анализа макро- и мегаконтинуумов экономической действительности, поэтому холотропность, проявлениями которой является осознанная синергия воли и эмерджентный эффект результатов, не выводится из персонифицированного эгоизма в условиях мира как дефицита. Социокультурная среда - это тот континуум, в котором холономность мира актуализируется в паттернальних практиках, мейнстримной наукой интерпретируется как деструктивные ограничения выбора и посягательство на экономическую свободу. Экономические институты, созданные на методологических подходах статической эффективности, стимулируют адаптивный потенциал когнитивного капитала, балансируя точки на кривой производственных возможностей по оптимуму Парето. Они не стимулируют поиск ренты с возможностей новых комбинаций эндаументальных активов.

Ключевые слова: клиометрическая модель; холотропность праксеологии; холономность аксиологии; нарратив; паттерн; maxutility; симулякр; идеационная культура.

\section{B. M. Shevchyk \\ Lviv University of Trade and Economics, Lviv, Ukraine}

\section{CLIOMETRICS AND HOLOTROPIC PRINCIPLE OF PRAXEOLOGY}

The ontological integrity of cognitive acts, acting as innovations in paternal practices of economy is studied and the limitation of the metrological tools of mainstream cliometrics to explain the holonomy of axiological dimension of being and phenomena of synergy in praxeology is grounded. To achieve the results of the study, an ontological approach is used, where the economic development is interpreted as intellectual bifurcation, which, through the mechanism of diffusion of innovations, shifts the output curve to the right. Cliometrics produces static models of optimum narratives in homeostatic space as universal tools of the assessment of the proportion of ideal being and real being in the past and ideal being and possible being in the future. It ignores the historical and cultural context of the analyzed era, where people could have their own goals, and not just maxutility. Mainstream pattern maxutility is a convenient and vulgar tool for the history trial and futuristic demagogy, not suitable for the analysis of reality, as it derives the public benefit of the private benefit that brings to Mandeville indulgence of lust and vice, where evil is a reason for good. The overcoming of socio-cultural determinism, where innovation is the result of the rupture of a cultural pattern is interpreted by the mainstream as a condition of the economic development; so the economic development is accompanied by multicultural vulgarization of being. The 
authors argue that a prerequisite for the innovative development of the economy is intelligible and cognitive act of creative unpacking of meanings of semantic vacuum and creating texts - projects of the possibility of more perfect being, the consuming value of which is ontological novelty. Words which are essentially consistent where the benefit of everyone follows a higher benefit, where attractive narratives of unity will activate the will for life as a common destiny of community existence. The historical process unfolds and terminates the measure of actualization of values in the life of the people, first of all, the experience of freedom, on the basis of which inclusive institutions of the forward-looking development of the economy, which create "windows of opportunities" for the transformation of innovative projects into paternal practices of praxeologic reality, are crystallized.

Keywords: cliometric model; holotropy of praxeology; holonomy of axiology; narrative; pattern; maxutility; simulacrum; ideation culture. 